\title{
Application of Polysaccharides as Structural Materials 多糖の構造材料としての応用
}

\author{
Iijima, Kazutoshi; and Hashizume, Mineo \\ Department of Industrial Chemistry, Tokyo University of Science, Shinjuku-ku, Tokyo 162-0826, Japan \\ FAX: +81-3-5261-4631, E-mail: mhashizu@ci.kagu.tus.ac.jp \\ (Received on July 28, 2014, accepted on September 26, 2014)
}

Key Words: polysaccharide, structural material, biomaterial, porous scaffold, film, fiber

\begin{abstract}
The preparation of materials from polysaccharides is important from both a functional and industrial aspect. In this review, after a brief explanation on the chemical structures and properties of the representative polysaccharides used in material chemistry, we described the preparation of structural materials, such as porous scaffolds, films, and fibers, from polysaccharides for biomedical applications, with a focus on polysaccharide species and fabrication methods and also discussed our own findings.
\end{abstract}

要 約

多糖からの材料の作製は機能面および産業面の両方の観 点から重要である。本総説では、材料化学分野で用いられ る代表的な多糖の化学構造と特性について簡潔に述べたあ と、多糖による生物医療応用のための多孔質足場、フィルム、 ファイバーなどの構造材料の作製について、多糖の種類や作 製方法に焦点を当てながら、またわれわれの研究成果も含め て解説する。

\section{A. Introduction}

Natural polysaccharides have been utilized as industrial products or raw materials, such as wood, paper, and cotton. In addition to such "classical" usages, materials with specific functions have recently been prepared from isolated polysaccharides through chemical modifications and/or novel manufacturing methods. The preparation of materials from polysaccharides is important not only because of the excellent functions of the resulting materials, based on the chemical and physical properties of polysaccharides, but also because it can contribute to the building of a sustainable society through the creation of environment-friendly materials and utilization of an abundant biomass. Since natural polysaccharides generally exhibit high biodegradability, good biocompatibility, and specific bioactivity based on their species, most materials made of them have been applied to the biomedical industry. In this review, after a brief explanation regarding the structures and properties of the polysaccharides used in material chemistry, especially in the biomaterial field, we summarized the preparation and application of biomaterials, mainly used as structural materials, from them, with a focus on polysaccharide species and fabrication methods, and also discussed our own findings.

\section{B. Structural Polysaccharides}

Cellulose is the most abundant biomass on the earth followed by chitin. Both polysaccharides play vital roles in maintaining the structures of living organisms: therefore they are called "structural polysaccharides." Cellulose is a homopolymer of D-glucose (D-

\section{A. 緒言}

人類は太古より木材、紙、綿のような形で天然多糖を産 業製品あるいはその原料として利用してきた。近年ではこの ような “古典的”な多糖の利用に加えて、単離した多糖を化 学的に改変したり、また（あるいは）調製法を工夫したりす ることで特異な機能が付与された材料が作製されている。多 糖からの材料の作製は、それらの化学的および物理的性質に 基づいた優れた機能のためだけでなく、環境にやさしい材料 の開発や生物資源の有効活用という観点からの持続可能な社 会の確立に貢献できるという点で重要である。天然多糖は一 般的に高い生分解性と優れた生体適合性を有し、種類によっ ては特異な生理活性を有することから、多糖からの材料作製 はバイオメディカル分野での利用を指向したものが多い。本 総説では、材料化学、特にバイオマテリアル分野において用 いられる多糖の構造と特性について簡潔に述べたあと、それ らによる主に構造材料としてのバイオマテリアルの作製と応 用について、多糖の種類や作製法に焦点を当てながら、われ われの結果も含めてまとめている。

\section{B. 構造多糖}

地球上に存在するバイオマスのうち最も量が多いものは セルロースであり、それに次ぐのがキチンである。どちらの 多糖も生物の構造を構成し維持するために重要な役割を果た しており、それゆえ構造多糖と呼ばれる。セルロースはD-グ 
(A)

D-GlC

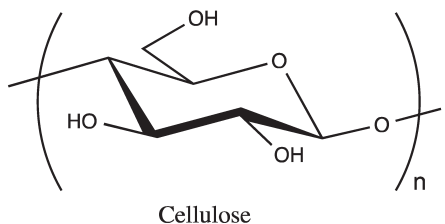

(D)
(B)

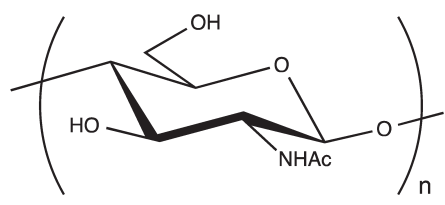

Chitin

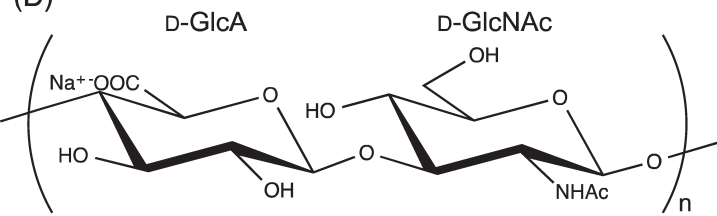

(F)
Hyaluronic acid sodium salt (Hyaluronan)

(E)

(C)

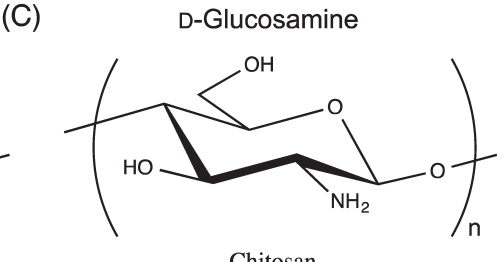

Chitosan
D-GICA OH D-GalNAc6S

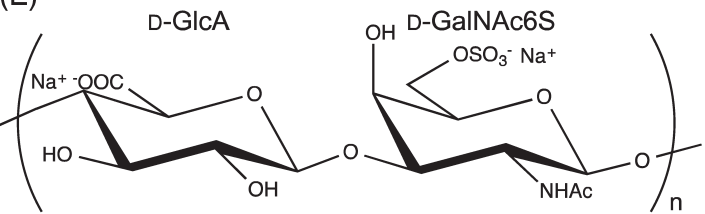

Chondroitin sulfate $\mathrm{C}$ sodium salt

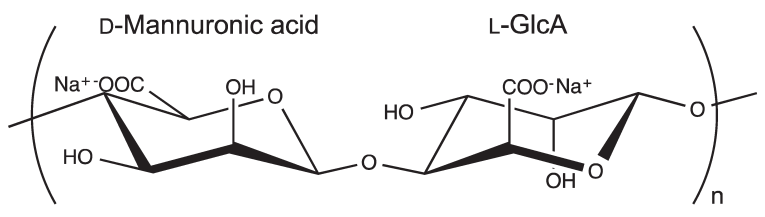

Sodium Alginate

Fig. 1. Chemical structures of some representative polysaccharides. (A) Cellulose, (B) chitin, (C) chitosan, (D) hyaluronic acid sodium salt (hyaluronan), (E) chondroitin sulfate $\mathrm{C}$ sodium salt, and (F) sodium alginate.

Glc) that is linked via $\beta(1 \rightarrow 4)$ linkages (Fig. 1A) and is the major component of cell walls. Sea squirts and some bacteria are also known to synthesize cellulose $(1,2)$. On the other hand, chitin is a homopolymer of $\mathrm{N}$-acetyl-D-glucosamine (GlcNAc) that is linked via $\beta(1 \rightarrow 4)$ linkages (Fig. 1B) and is the major component of the exoskeletons of crustaceans and insects $(1,3)$. Although many hydroxyl groups exist in both polysaccharides, they are not soluble in water because of their high crystallinities. Crystallographic studies revealed that the $\beta(1 \rightarrow 4)$ linkages among the glucose monomer units in cellulose caused the conformation of cellulose molecules to become linearly extended, making them form intra- and intermolecular hydrogen bonding networks among their multiple hydroxy groups. Such a conformation and multiple hydrogen bonds have been shown to induce the self-assembly of cellulose molecules for the formation of crystalline fiber structures $(4,5)$. Similar hydrogen bonding networks have also been identified in crystalline chitin, parts of which are constructed by acetamide groups and hydroxy groups $(6,7)$. Although these polysaccharides are strongly utilized as functional materials because of their abundance in nature, current demands remain unsatisfied. One reason for this is the difficulties are associated with preparing materials from these polysaccharides because of their water insolubility. Therefore, novel processes and/or the derivatization of the polysaccharides themselves, for example, the deacetylation of chitin to obtain chitosan (Fig. 1C) need to be developed. In addition to cellulose and chitin, other polysaccharides such as pectin, agarose and carrageenan are
ルコース (D-Glc) が $\beta(1 \rightarrow 4)$ 結合したホモポリマーであり（図 1A）、植物の細胞壁の主な構成成分である。ホヤやある種の バクテリアによっても合成される $(1,2)$ 。一方、キチンは $N$ アセチル-D-グルコサミン (GlcNAc) が $\beta(1 \rightarrow 4)$ 結合したホ モポリマーであり（図 1B）、甲殼類や昆虫類の外殼の主な構 成要素である $(1,3)$ 。セルロースやキチンはその構造中に多 数の水酸基を有するものの、高い結晶性を有し、水に不溶で ある。セルロースにおいては、結晶構造の解析よりグルコー スモノマーユニット間の $\beta(1 \rightarrow 4)$ 結合がセルロース分子を直 線状に伸びきったコンフォメーションとし、それにより多数 のヒドロキシ基によって分子内および分子間の水素結合ネッ トワークが形成されていることが明らかとなっている。その ようなコンフォメーションと多価の水素結合がセルロース分 子の自己集合による結晶性のファイバー構造の形成を誘起し ている $(4,5)$ 。同様の水素結合ネットワークはキチンにおい ても見られるが、その一部はアセトアミド基とヒドロキシ基 によって構築されている $(6,7)$ 。これらの構造多糖は自然界 における存在量が非常に多いために機能材料としての有用化 に対する要求は強いが、その現状は依然として満足できるも のではない。一つの理由は、それらから材料を作製する際に しばしばそれらの取り扱いを困難にしている水不溶性にあ る。したがって、新しい操作法の開発および（あるいは）キ チンの脱アセチル化によってキトサン（図 1C）を得るよう な誘導体化が必要となっている。セルロース、キチンに加え てペクチン、アガロース、カラギーナンなども構造多糖に属 
also structural polysaccharides and are used as the raw materials of various biomaterials.

\section{Non-structural Polysaccharides}

Among the non-structural polysaccharides, glycosaminoglycans such as hyaluronic acid (hyaluronan), chondroitin sulfate $\mathrm{A} / \mathrm{C}$, heparan sulfate and heparin as well as pullulan, dextran, and alginic acid (alginate) have been used in the fabrication of biomaterials. Most of these are water-soluble and easier to handle and mold than structural polysaccharides. Furthermore, many possess bioactivities or specific molecular recognizabilities, which are consciously utilized for the preparation of functional biomaterials.

Hyaluronan is composed of glucuronic acid (GlcA) and GlcNAc and has repeated structures of the -D-GlcA- $\beta(1 \rightarrow 3)$-DGlcNAc- $\beta(1 \rightarrow 4)$ - unit (Fig. 1D). It is the major glycosaminoglycan component in vitreous humor and spinal fluid. Hyaluronan molecules strongly bind to water molecules or metal ions, which produces its characteristic viscous properties. In living bodies, these properties play important roles as shock absorbers or lubricants. Hyaluronan has conventionally been extracted from bovine vitreous humor or rooster combs. It was recently produced successfully on a large scale by fermentation methods using lactic acid bacteria such as Streptococcus zooepidemicus and Streptococcus equi with good yield, which overcome the problems associated with production amounts and costs.

Many glycosaminoglycans are sulfonated and typically conjugated with proteins to form proteoglycans that exist as the major component of extracellular matrices in various animals. Chondroitin sulfate A (or chondroitin 4-sulfate) consists of GlcA and GlcNAc, the 4-positions of hydroxyl groups of which are sulfonated, whereas the 6-position of the hydroxyl group of the GlcNAc is sulfonated in chondroitin sulfate $\mathrm{C}$ (or chondroitin 6-sulfate, Fig. $1 \mathrm{E})$. They have been detected in cartilage as the polysaccharide parts of proteoglycans. Heparin contains multiple sulfate groups in its repeating structure and exhibits anticoagulant activity against blood (8).

Alginate (Fig. 1F), another non-structural polysaccharide and linear alternate co-polymer of D-mannuronic acid and $\alpha$-L-GlcA via $\beta(1 \rightarrow 4)$ linkages, is also widely used as a biomaterial. Alginate is extracted from brown algae. $\alpha$-L-GlcA blocks of more than 6-10 residues form stable cross-linked junctions ("egg box" structure), which induce gelation, in the presence of divalent cations (including $\mathrm{Ca}^{2+}, \mathrm{Ba}^{2+}$, and $\left.\mathrm{Sr}^{2+}\right)(9,10)$. In addition to their use in food industries, these alginate gels have been widely used in the preparation of soft biomaterials.

As described above, the physical and chemical properties of many types of natural polysaccharides are known to differ. There-
し、さまざまなバイオマテリアルの原料として利用されてい る。

\section{C. 非構造多糖}

非構造多糖の中では、ヒアルロン酸やコンドロイチン硫 酸 $\mathrm{A} / \mathrm{C} 、 ヘ ハ ゚ ラ ン$ 硫酸、ヘパリンなどのグリコサミノグリカ ンやプルラン、デキストラン、アルギン酸などがバイオマテ リアルの原料として用いられてきた。それらのほとんどは水 溶性が高く、構造多糖と比較して取扱いや成型加工がより容 易である。また、生体において生理活性や特異的な分子認識 能を有しているものも多く、それらを意識的に利用した生体 材料も開発されている。

ヒアルロン酸はグルクロン酸（GlcA）とGlcNAcの2 糖 を構成成分とし、-D-GlcA- $\beta(1 \rightarrow 3)$-D-GlcNAc- $\beta(1 \rightarrow 4)$-の繰り 返し構造からなる（図 1D）。それは硝子体や髄液に存在する 主要なグリコサミノグリカン成分である。ヒアルロン酸分子 は水分子や金属イオンに強く結合する性質を有し、これが特 徴的な粘性を生じる。生体においてはこのような性質が衝撃 吸収や潤滑油の役割を担っている。従来、ヒアルロン酸はウ シ硝子体液やニワトリのとさかより抽出されてきた。最近で は乳酸菌の一種である Streptococcus zooepidemicus や Streptococcus equi を用いた発酵法により大スケールにて高収率に得 られるようになり、供給量やコスト上の問題点が克服されつ つある。

多くのグルコサミノグリカンは硫酸修飾を受け、通常夕 ンパク質と結合してさまざまな動物の細胞外マトリックスの 主成分であるプロテオグリカンとなる。コンドロイチン硫酸 A（コンドロイチン 4 硫酸）は GlcA と 4 位の水酸基が硫酸化 されたGlcNAcからなり、コンドロイチン硫酸C（コンドロ イチン 6 硫酸, 図 $1 \mathrm{E})$ は GlcA と 6 位の水酸基が硫酸化され たGlcNAcからなる。これらの糖は軟骨組織においてプロテ オグリカンの糖鎖部分として存在する。ヘパリンはその繰り 返し配列中に多数の硫酸基を有し、血液に対する抗凝固活性 を示す $(8)$ 。

もう一つの非構造多糖であり D-マンヌロン酸と $\alpha$-L-GlcA が $\beta(1 \rightarrow 4)$ 結合したアルギン酸（図 $1 \mathrm{F）もまたバイオマテ}$ リアルとして広く用いられている。アルギン酸は褐藻類から の抽出により製造される。 $\mathrm{Ca}^{2+}, \mathrm{Ba}^{2+}, \mathrm{Sr}^{2+}$ など 2 価のカチオ ンの存在下で 6-10残基以上からなる $\alpha-\mathrm{L}-\mathrm{GlcA}$ ブロックにお いて “egg box” $(9,10)$ と呼ばれる安定な架橋構造を形成し ゲル化する。食品産業での利用に加えて、これらアルギン酸 ゲルはソフトなバイオマテリアル作製に用いられている。 このように天然には多様な種類の多糖が存在し、その物 

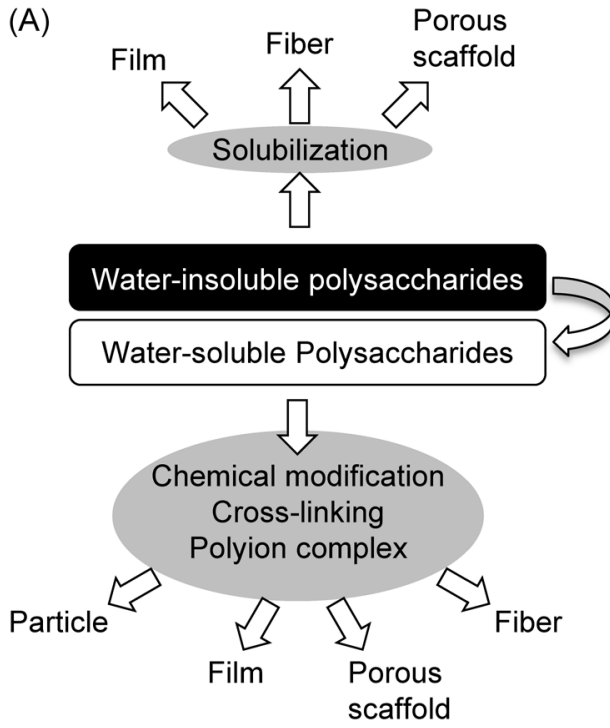

(B)

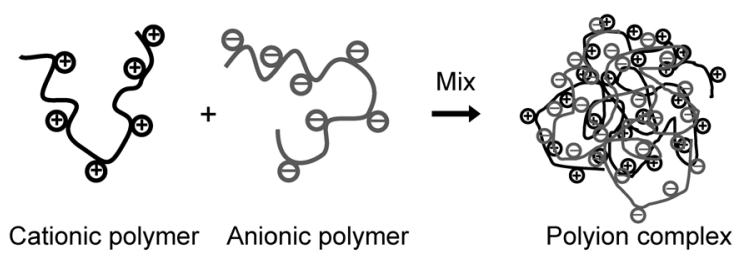

(C)

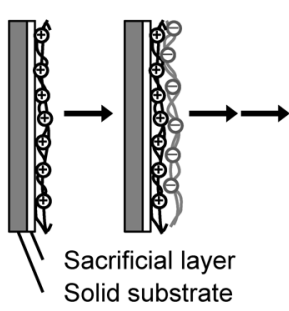

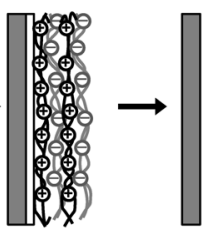

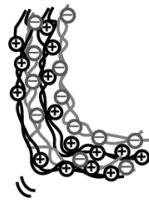

Free-standing ultrathin film

Fig. 2. Preparation of non-structural and structural materials from polysaccharides. (A) Overview of the preparation of materials from polysaccharides, (B) formation of water-insoluble polyion complexes from cationic and anionic polymers, and (C) formation of freestanding ultrathin films by the layer-by-layer (LbL) assembly technique.

fore, the process of preparing these materials strongly depends on the kinds of polysaccharides used. An overview of the preparation of materials from polysaccharides is shown in Fig. 2A.

\section{Creation of Non-structural Materials from Polysac- charides}

Chitosan, obtained from hydrolyzing the acetyl groups of chitin, is widely used in the preparation of various kinds of biomaterials because of its solubility in weak acids such as acetic acid or formic acid, which allow for easier handling, and because it is a basic polymer rarely found in natural polysaccharides. Chitosan forms polyion complex (PIC, Fig. 2B) particles when mixed with acidic polymers including DNA in aqueous solutions: therefore, the use of such particles as gene delivery carriers has been investigated (11-13). Through treatments with cross-linking agents, such as glutaraldehyde, chitosan is now used as a protein delivery carrier (14).

The recent development of characterization techniques for nanomaterials has focused on renewed attention on polymer hydrogels having nanometer sizes as "nanogels." Akiyoshi et al. extensively investigated the preparation and applications of nanogels prepared from the derivatives of polysaccharides such as pullulan, dextran, mannan, and hyaluronan. These nanogels are formed by the self-association of polysaccharide molecules in which small amounts of their hydroxy groups have been modified with hydrophobic groups such as cholesterol or an alkyl chain (15) (Fig. 3). Some of these nanogels act as drug delivery carriers (16) and vaccines (17), and also exhibit chaperon-like functions (18).

The novel chemical functions of polysaccharides have been
理的・化学的性質が大きく異なっており、それらを原料とす る材料作製の手法もさまざまである。図 $2 \mathrm{~A} に$ 多糖からの材 料作製の概略図を示す。

\section{D. 多糖からの非構造性材料の創製}

キチンのアセチル基の加水分解により得られるキトサ ンは酢酸やギ酸などの弱酸に可溶なため取り扱いが容易と なり、また生体由来の多糖の中で数少ない塩基性高分子で あることからさまざまな種類の生体材料の作製に幅広く用い られている。キトサンは水溶液中で核酸を含む酸性高分子と の混合によってポリイオンコンプレックス（PIC, 図2B）微 粒子を形成するため、そのような微粒子の遺伝子デリバリー キャリアとしての利用が検討されてきた(11-13)。グルタル アルデヒドのような架橋剤で処理することにより、キトサン はタンパク質デリバリーのキャリアとしても応用されている (14)。

近年のナノ材料の分析技術の発展により、ナノメートル サイズの高分子ハイドロゲルが “ナノゲル”として再び注目 を集めている。秋吉らはプルラン、デキストラン、マンナン、 ヒアルロン酸などの多糖の誘導体からのナノゲルの作製と応 用について精力的に研究を進めている。これらナノゲルはコ レステリル基やアルキル鎖といった疎水性基でヒドロキシ基 の一部を修飾した多糖分子の自己集合により形成される (15) (図3)。これらナノゲルのいくつかは薬物輸送キャリア (16)、 ワクチン (17) としての役割を果たすほか、シャペロン様の 機能(18) を有することが知られている。

糖の新たな化学的機能の探索が多くの研究者によって行 


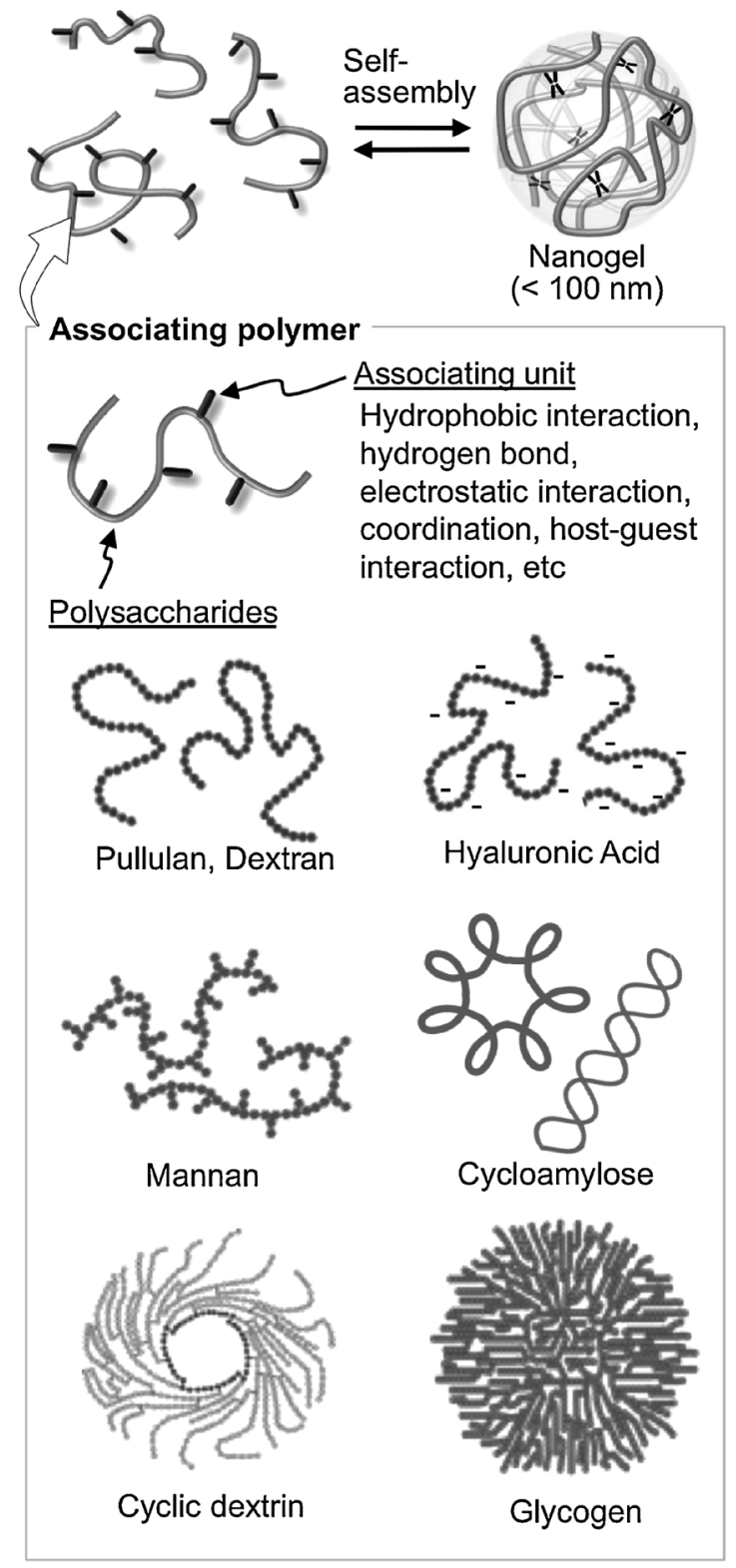

explored in many studies. Serizawa et al. recently demonstrated that water-dispersible crystalline cellulose nanofibers exhibited hydrolytic activity for esters, monophosphates, and amide molecules (19). More unknown chemical functions of polysaccharides may still exist and are expected to be unveiled in future studies.

\section{E. Structural Materials from Polysaccharide-Porous Scaffolds}

A porous scaffold is a three-dimensional structural material for biomedical use and can be prepared from polysaccharides (Table 1). In addition to its application as a drug carrier (20) - in this case "porous carriers" typically have markedly smaller pores than those of porous scaffolds-polysaccharide porous materials
Fig. 3. Concept of nanogels prepared from derivatives of polysaccharides. Reprinted with permission from ref. 15. Copyright 2012 Chemical Society of Japan.

われている。近年、芹澤らは水中分散性の結晶セルロースナ ノファイバーがエステル、モノリン酸、アミドなどの分子に 対して加水分解活性を示すことを見いだした(19)。この研究 以外にも多糖には未知の活性が存在する可能性がある。今後 の研究によりそれらが明らかになることが期待される。

\section{E. 多糖からの構造性材料の創製一多孔質足場}

多孔質足場（scaffold）は生物医学利用のための構造材 料の一つであり、多糖から作製することができる（表1）。 薬物担体としての利用 (20)—この場合、通常多孔質足場より ももっと小さい孔をもつ“多孔質担体”一に加えて、多糖多 孔質材料は軟骨組織や椎間板、骨組織の組織工学における細 胞足場として利用されうる。これら多孔質足場はキチン (21) 
can be applied as cell scaffolds in cartilage tissue, intervertebral disc tissue, and bone tissue engineering. These porous scaffolds are made of various types of polysaccharides such as chitin (21), chitosan (22), chondroitin sulfate (23), and alginate (24) (Table 1). The lyophilization (22) and internal bubbling process (IBP)
やキトサン (22)、コンドロイチン硫酸 (23)、アルギン酸 (24) など、さまざまな多糖より作製されている（表1）。調製法 としては主に溶液からの凍結乾燥 (22) あるいは internal bubbling process（IBP）（21）が用いられる。凍結乾燥による手法 では、凍結乾燥による氷の除去が、凍結過程での冷却速度や

Table 1. Structural materials made of polysaccharides

\begin{tabular}{|c|c|c|}
\hline Polysaccharide & Form & Methods and compositions \\
\hline \multirow[t]{3}{*}{ Chitin } & Porous scaffold & $\mathrm{CaCO}_{3}$ internal bubbling process $(21)$ \\
\hline & Film & Spin-coating (32), trimethylsilylation (33) \\
\hline & Fiber & Wet-spinning $(56,57)$ \\
\hline \multirow[t]{6}{*}{ Chitosan } & Porous scaffold & $\begin{array}{l}\text { Lyophilization (22), chitosan/hydroxyapatite (25-27), chitosan/collagen (28), chitosan/hyaluronan/gelatin } \\
\text { ternary Complex (29), maleic chitosan/PEGDA hybrid hydrogel(30), chitosan/silk fibroin/hydroxyapatite } \\
\text { (31) }\end{array}$ \\
\hline & Fiber & Wet-spinning (58-60), electrospinning (61) \\
\hline & PIC fiber & $\begin{array}{l}\text { Interface-spinning with gellan }(62,63) \text {, gellan sulfate }(64) \text {, poly }(\alpha, L \text {-glutamic acid) }(65) \text {, chondroitin sulfate } \\
\quad \text { C (66) }\end{array}$ \\
\hline & Film & Cast (cross-linked with glutaraldehyde) $(34,35)$ \\
\hline & LbL film & Poly (styrenesulfonate) (42), dextrane sulfate (43), hyaluronan (44), heparin (45), alginate $(46,50,51)$ \\
\hline & PIC film & Hot press method with chondroitin sulfate C (52) \\
\hline Cellulose & Film & TEMPO-mediated oxidation (36), composite with resin $(37,38)$ \\
\hline Chondroitin sulfate & Porous scaffold & Chondroitin sulfate/collagen (23) \\
\hline Hyaluronan & LbL film & Poly(L-lysine) (53) \\
\hline \multirow[t]{2}{*}{ Alginate } & Porous scaffold & Alginate/galactosylated chitosan (24) \\
\hline & Fiber & Alginate-Ca composite with hydoxyapatite $(67)$, microfluidics $(68,69)$ \\
\hline kappa-Carrageenan & Film & Cast (composite with chitosan) (54) \\
\hline iota-Carrageenan & Film & Cast (55) \\
\hline
\end{tabular}

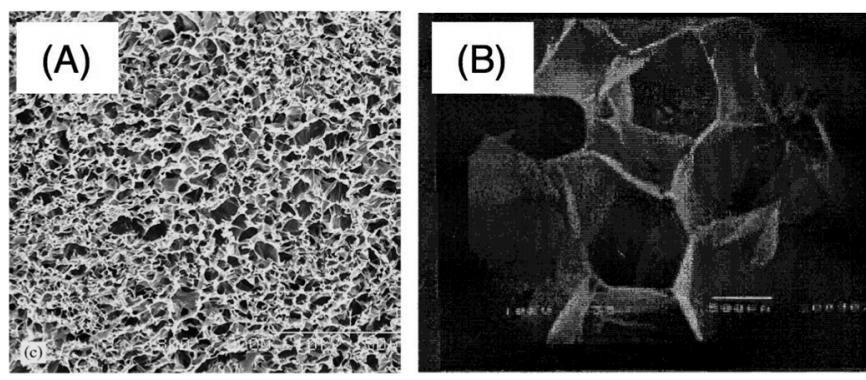

(C)

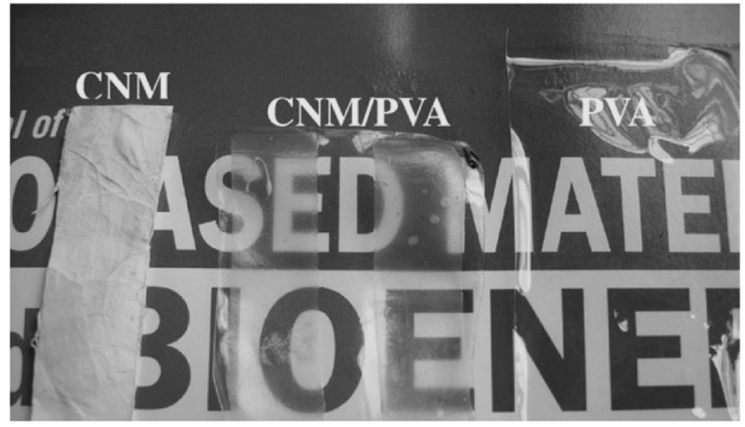

Fig. 4. Examples of structural materials from polysaccharides. (A) Scanning electron microscopic (SEM) image of a scaffold made of chitosan using lyophilization, (B) SEM image of chitin porous matrixes produced by internal bubbling process using $\mathrm{CaCO}_{3}$, and $(\mathrm{C})$ appearance of cellulose nanofibrous mat (CNM)/poly(vinyl alcohol) (PVA) composite film contains $40 \mathrm{wt} \% \mathrm{CNM}$. Reprinted with permission from ref. 22 (Copyright 1999 Elsevier Science Ltd.), ref. 21 (Copyright 2000 American Chemical Society.) and ref. 37 (Copyright 2008 Elsevier Ltd.), respectively. 
(21) of polysaccharide solutions are mainly used as the preparation process. In the case of the lyophilization process, ice removal by lyophilization generates porous materials, the pore size and orientation of which can be controlled by varying the freezing rate, ice crystal size, and geometry of thermal gradients during freezing (Fig. 4A). On the other hand, in the case of IBP, $\mathrm{CaCO}_{3}$ is firstly added into polysaccharide solutions to form polysaccharide$\mathrm{CaCO}_{3}$ gels. They are then treated with $\mathrm{HCl}$ solution to produce $\mathrm{CO}_{2}$, which makes the gel porous (Fig. 4B). The porous materials obtained by both methods can be processed in various forms such as films, blocks, beads, and tubes. Furthermore, porous scaffolds have been prepared not only from polysaccharides themselves that gelate by cross-linking or the formation of PICs, but also from hybrids of polysaccharides with other biocompatible materials such as hydroxyapatite (25-27) or collagen (28). Strategies to design or modify biomechanical strength or cell-matrix interactions are also being developed. For example, porous scaffolds made of collagen and chondroitin sulfate that mimic components of cartilage tissue were prepared and their mechanical properties were evaluated (23).

\section{F. Structural Materials from Polysaccharides-Films}

Films are two-dimensional structural materials and can be applied to permselective membranes, wound dressings, skin substitutions, and cell scaffolds used in tissue engineering and regenerative medicine (Table 1). If the polysaccharides used have high water solubility, PIC formations such as the DNA/chitosan complexes described above, or chemical modifications, in the case of nanogel preparations, are needed to prepare water insoluble materials from these polysaccharides. On the other hand, water-insoluble structural polysaccharides such as cellulose and chitin can form water-insoluble materials without these modifications if the difficulties associated with the precise structural control of the material can be overcome. For example, chitin is soluble in a limited number of solvents such as $\mathrm{LiCl} / N, N$-dimethylformamide (DMF), formic acid and $\mathrm{CaCl}_{2} \cdot 2 \mathrm{H}_{2} \mathrm{O}$-saturated methanol; therefore, chitin films can be prepared by spin-coating these chitin solutions (32). Chitin ultrathin films can also be obtained by spin-coating solutions containing chitin derivatives, the hydroxyl groups of which are trimethylsilylated to dissolve in commonly used organic solvents, followed by detrimethylsilylation using acid solutions (33). Chitosan can also be formed into thin films by casting solutions and suspensions: however, cross-linking treatments such as that using glutaraldehyde are required to decrease water solubility for their use as structural materials $(34,35)$. The preparation of films made of cellulose nanofibers has been conducted. Transparent films were prepared using cellulose nanofibers treated with 2,2,6,6-tetramethylpiperidine 1-oxyl (TEMPO)-oxidization (36)
水の結晶サイズ、温度分布などを制御することによって孔径 や配向性を制御することができるような多孔質材料を生み出 す (図 4A)。一方、IBP では始めに $\mathrm{CaCO}_{3}$ を多糖溶液に添加 して多糖- $\mathrm{CaCO}_{3}$ ゲルを形成させる。次にそれらは $\mathrm{CO}_{2}$ を発 生させるために塩酸溶液で処理され、それによってゲルは多 孔質となる (図4B)。いずれの方法で得られた多孔質材料も 膜、ブロック、ビーズ、チューブなど種々の形態に加工可能 である。また、架橋やPIC形成によりゲル化した多糖そのも のだけでなく、ヒドロキシアパタイト(25-27) やコラーゲン （28）など他の生体適合性材料と複合した多孔質担体も作製 される。多孔質担体の生体力学特性や細胞-基質相互作用を 設計、改変する手法も開発されている。たとえば生体の軟骨 組織の組成を模倣したコラーゲンとコンドロイチン硫酸から なる多孔質担体が作製され、その力学的特性が評価された $(23)$ 。

\section{F. 多糖からの構造性材料の創製一フィルム}

フィルムは二次元の構造材料であり、選択的透過膜や創 傷被覆材、皮膚置換材、組織工学や再生医療に用いられる細 胞培養足場としての応用が考えられる（表1）。もし利用す る多糖が高い水溶性をもつならば、これら多糖から水不溶性 の材料を作製しようとする場合には上述のDNA／キトサン 複合体のようなPICの形成や、あるいはナノゲル作製の場合 のように化学修飾が必要となる。一方、もし材料の精密な構 造制御における困難さを克服できるのであれば、セルロース やキチンなどの水不溶性である構造多糖はこれらの修飾なし に水不溶性の材料を形成することができる。たとえば、キチ ンは $\mathrm{LiCl} / N, N$-dimethylformamide $(\mathrm{DMF}) 、 キ ゙$ 酸、 $\mathrm{CaCl}_{2} \cdot 2 \mathrm{H}_{2} \mathrm{O}$ 飽和メタノールなどのごく限られた溶媒には溶解するため、 それらのキチン溶液のスピンコートによりキチンフィルムを 作製することができる (32)。また汎用有機溶媒に対して可溶 化するためヒドロキシ基をトリメチルシリル化したキチン誘 導体を含む溶液のスピンコートおよび引き続いての酸溶液に よる脱トリメチルシリル化によってもキチン超薄膜が得られ る $(33)$ 。キトサンも溶液や懸濁液をキャストすることによ りフィルムへと成型できるが、構造材料として利用するに は水溶性を低下させるためグルタルアルデヒドなどによる 架橋が必要となる $(34,35)$ 。ルロースナノファイバーから フィルムの作製も行われている。セルロースナノファイバー の 2,2,6,6-tetramethylpiperidine 1-oxyl (TEMPO) 酸化(36) や 他の樹脂や高分子との複合化 $(37,38)$ により、透過率が高 く、優れた力学的特性を示すフィルムが作製されている（図 $4 \mathrm{C})$ 。 
and those mixed with other resin or polymers (Fig. 4C) $(37,38)$.

Regarding water-soluble polysaccharides, the layer-by-layer (LbL) assembly technique, in which substrates are alternately immersed into oppositely charged polyelectrolyte solutions, is useful for preparing ultrathin composite films of polysaccharides and polyelectrolytes or polysaccharides having opposite charges at molecular precisions (Fig. 2C) (39-41). Relatively thick films can also be prepared using this technique by repeating the assemblies many times. Various compositions of LbL films such as those of poly(styrenesulfonate) and chitosan (42), dextran sulfate and chitosan (43), hyaluronic acid and chitosan (44), heparin and chitosan (45), and alginate and chitosan (46) are readily obtained. When ultrathin films are prepared on sacrificial layers formed on solid substrates, free-standing ultrathin films can be obtained by dissolution of the sacrificial layers (Fig. 2C) (47-49). Using such an approach, Takeoka et al. prepared ca. 30-nm-thick free-standing alginate/chitosan LbL films (50). Since such films exhibit self-adhesive abilities to tissues due to their thinness, their potential application as biocompatible "nano-adhesive plasters" has been investigated (51).

On the other hand, we previously demonstrated that freestanding polysaccharide composite films having thicknesses of several tenths of micrometers could be readily obtained using the hot press technique (52) (Figs. 5A and B). These thicker films had sufficient mechanical strength and were markedly easier to handle than those with nanometer thicknesses. Furthermore, thicker films can load larger amounts of drugs when used as drug carriers. Briefly, the procedure used to prepare free-standing films of chondroitin sulfate $\mathrm{C}$ and chitosan is as follows. Aqueous solutions of chondroitin sulfate $\mathrm{C}$ and those of chitosan (containing acetic acid) are mixed, which results in the formation of their PICs. These PICs are isolated using lyophilization or centrifugation then formed into thin films by hot pressing. The simple hot pressings of PICs failed to obtain homogeneous free-standing films. Systematic experiments under various conditions revealed optimal film preparation conditions. Free-standing heparin/chitosan and hyaluronan/ chitosan films can also be obtained using similar procedures. The thickness of film can be controlled by altering the thickness of the plastic sheets used as spacers. The resulting films have homogeneous, smooth surfaces and dense structures at the microscopic level (Figs. 5C and D). PICs can also be formed into thin films by casting their suspension: however, it is hard to obtain films having a homogenous thickness and surface smoothness. The polysaccharide composite films obtained by our process swell but are not dissolvable in water. These polysaccharide composite were films found to induce the deposition of hydroxyapatite on their surfaces under body fluid conditions. In addition, our recent findings supported these films being useful as sustained drug release carriers
水溶性多糖においては、基板を反対電荷を有する高分 子電解質の溶液に交互に浸漬させる交互積層（layer-by-layer $(\mathrm{LbL}))$ 法によって、多糖とその反対電荷をもつ高分子電解 質あるいは多糖との複合超薄膜を分子レベルの精密さで作製 することができる（図2C）（39-41）。比較的厚いフィルムも 集積を何度も繰り返すことにより本手法で作製することが できる。ポリスチレンスルホン酸ーキトサン (42)、デキスト ラン硫酸-キトサン (43)、ヒアルロン酸-キトサン (44)、ヘパ リンーキトサン (45)、アルギン酸_キトサン (46) といったさ まざまな組み合わせの LbL フィルムが容易に得られる。固体 基板の上に形成した犠牲層上に超薄膜を作製し、犠牲層を溶 解させることで自立型の超薄膜を得ることができる（図 $2 \mathrm{C}$ ) (47-49)。この手法により武岡らは約 $30 \mathrm{~nm}$ の厚みの自立型 アルギン酸／キトサン LbL フィルムを得た $(50)$ 。このような フィルムはその薄さより組織に自発的に貼り付くことから、 生体適合性の “ナノ絆創膏” としての利用が検討されている (51)。

一方、われわれは熱プレス法を活用することで数十マイ クロメートルの厚みを有する自立型多糖複合フィルムが簡便 に作製できることを示してきた(52)（図 5A, B)。このような より厚いフィルムはナノメートル厚の超薄膜と比べて十分な 力学的強度があり扱いやすい。加えて薬物担体として利用す る場合、より厚いフィルムはより大量の薬剤を担持できる。 コンドロイチン硫酸 Cとキトサンからなる自立フィルムの作 製についての手順を簡潔に述べると以下のようになる。はじ めにコンドロイチン硫酸 $\mathrm{C}$ の水溶液とキトサンの水溶液（酢 酸を含む）を混合することで両多糖による PICを作製する。 PIC は遠心分離あるいは凍結乾燥によって単離され、続いて 熱プレスによって薄膜へと成型される。単にPICを熱プレス しただけでは均質な自立フィルムは得られない。さまざまな 条件における系統的な実験はわれわれに最適なフィルム作製 条件を教えてくれる。同様の手法でヘパリンーキトサンおよ びヒアルロン酸-キトサン自立フィルムも得ることができる。 フィルムの膜厚はスペーサーとして用いているプラスチック シートの厚みによって制御可能である。得られたフィルムは 微視的に見ても均一で平滑な表面をもち、緻密な構造であっ た（図 5C, D）キャスト法によっても PICを薄膜に成型する ことはできるが、表面が平滑で均一な厚みのものを得るのは 困難である。われわれの方法で得られる多糖複合フィルムは 水中では膨潤するものの、不溶である。これら多糖複合フィ ルムは体液環境下においてヒドロキシアパタイトの析出を誘 起することも明らかになっている。最近われわれは、これら のフィルムに低分子化合物を取り込ませることができるこ 
(A)

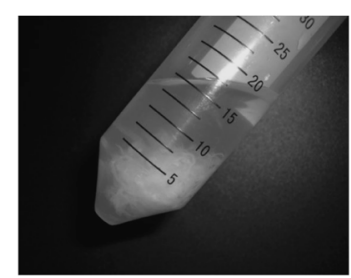

Chondroitin sulfate $\mathrm{Cl}$ Chitosan gel

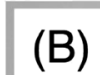

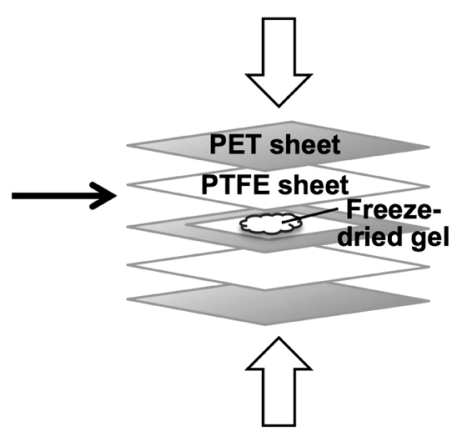

Hot pressing
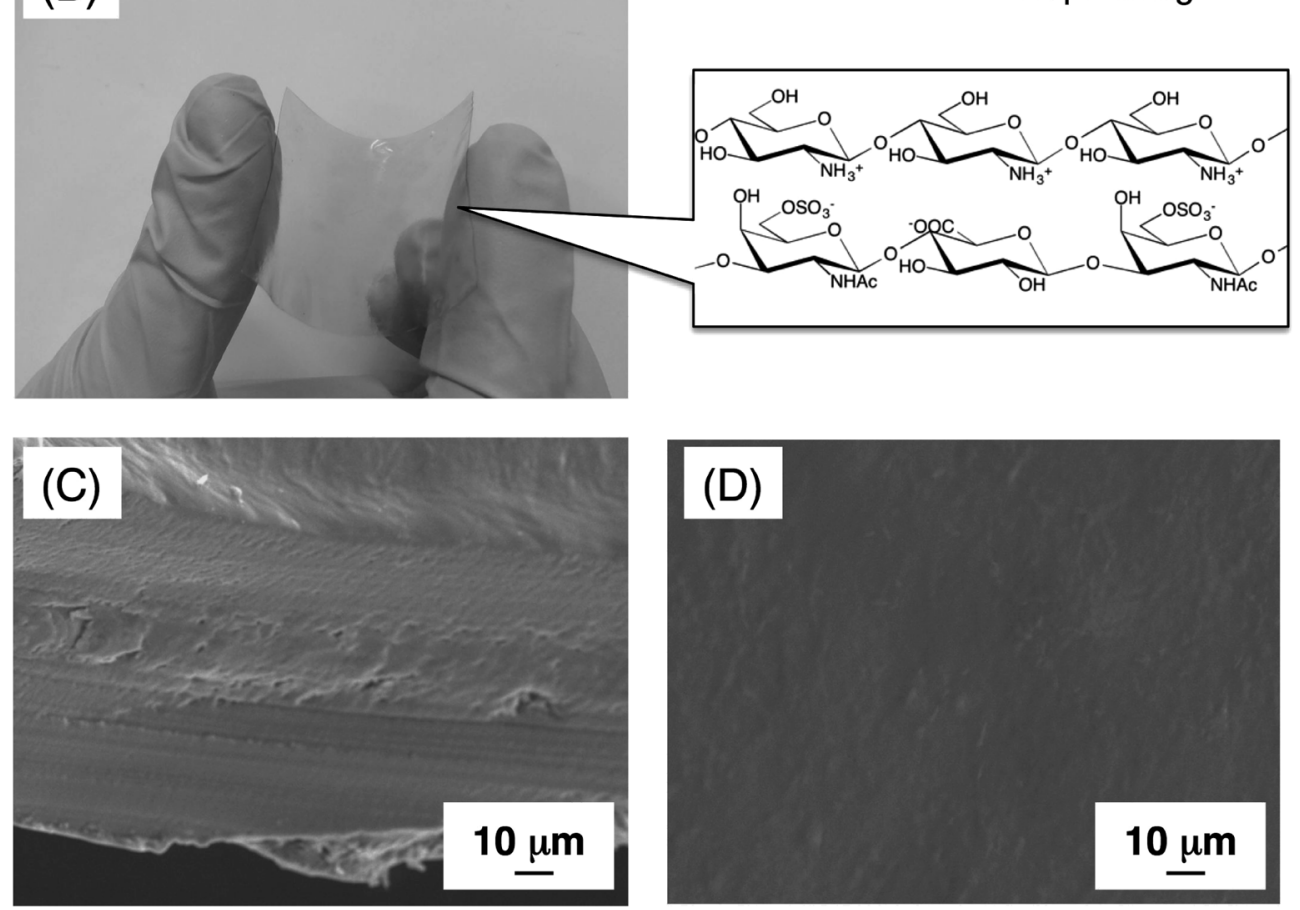

Fig. 5. Preparation of films from chondroitin sulfate $\mathbf{C}$ and chitosan using hot-press technique. (A) Overview of film formation using the hot-press technique, (B-D) macroscopic image (B) and scanning electron microscopic (SEM) images of a cross-sectional (C) and surface (D) of chondroitin sulfate C/chitosan films.

because they can incorporate small water-soluble organic molecules and release them when they are immersed in water. These properties of our polysaccharide composite films indicate their potential application in the biomedical field.

\section{G. Structural Materials from Polysaccharides-Fibers}

Fibers, one-dimensional objects, are regarded as another shape for structural materials made of polysaccharides (Table 1). Biocompatible fibers are useful not only as absorbable surgical sutures but also as unit components for the construction of more complex materials such as textile fabrics and hierarchical threedimensional scaffolds. Chitin was previously shown to be solubilized in a manner similar to that of chitin film preparations and was formed into fibers using the wet spinning process $(56,57)$.
と、水中に浸漬させることでこれらの分子が放出されること を見いだしており、薬物徐放担体として有用であるとも考え られる。われわれの多糖複合フィルムのこれらの性質はフィ ルムの生物医療分野での応用の可能性を示している。

G. 多糖からの構造性材料の創製一ファイバー 多糖からなる構造材料の別の形態として、一次元体であ るファイバーが挙げられる（表1）。生体適合性のファイバー は手術用縫合糸としての利用だけでなく、織物や階層的な三 次元足場など、より複雑な構造体を構築するための単位要素 として有用である。フィルム作製の場合と同様にキチンは 可溶化され湿式紡糸法によりファイバーへと成型される $(56$, 

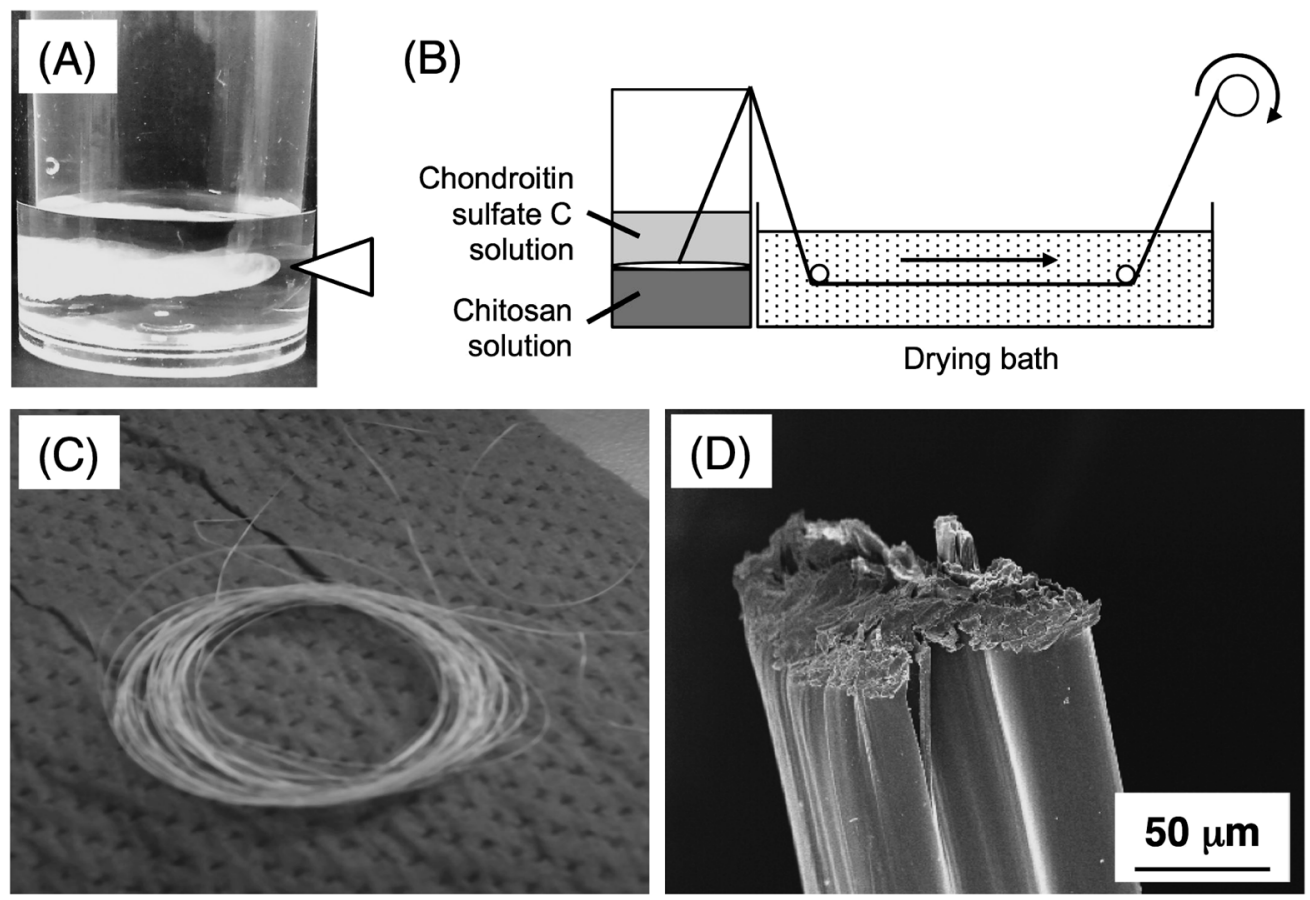

Fig. 6. Preparation of fibers from chondroitin sulfate $\mathbf{C}$ and chitosan. (A) Formation of films made of their PICs at the interfaces, (B) schematic illustration of the interface-spinning method, and (C-D) macroscopic image (C) and scanning electron microscopic (SEM) image (D) of chondroitin sulfate C/chitosan fibers.

Chitosan fibers have been prepared using wet spinning (58-60) and electrospinning (61) methods and used for the preparation of woven and non-woven fabrics. Composite fibers using polysaccharide PICs can be prepared in the same manner as film preparations. Yamamoto et al. (62-65) previously prepared polysaccharide PIC fibers using the interface-spinning method.

We reported the preparation of polysaccharide composite fibers with a diameter of several tenths of micrometers from chondroitin sulfate $\mathrm{C}$ and chitosan using interface-spinning methods (66). An aqueous solution of chondroitin sulfate $\mathrm{C}$ was gently placed on a chitosan solution, which resulted in the formation of films made of their PICs at the interfaces (Fig. $6 \mathrm{~A})$. Fibers were then spun by withdrawing the films from the interfaces, dried by passing through an organic solvent bath, and finally rolled up (Fig. 6B). Using these procedures, waterinsoluble fibers were obtained from water-soluble polysaccharides without using the cross-linking or chemical modification of polysaccharides. Chondroitin sulfate/chitosan composite fibers were dense and had diameters of $c a .100 \mu \mathrm{m}$ (Figs. 6C and D). The effects of the molecular weight of chitosan on fiber formability have been examined. Fibers cannot be obtained from the low molecular weight of chitosan and those prepared using higher molecular weights have exhibited slightly higher tensile strengths.
57)。キトサンファイバーは湿式紡糸法(58-60) や電界紡糸 法(61) により作製され、織布、不織布の作製に用いられて いる。フィルム作製と同様に多糖PICからなる複合ファイ バーが作製されている。山本ら（62-65）は界面紡糸法により 多糖同士のPICからなるファイバーを作製してきた。

われわれはコンドロイチン硫酸 Cとキトサンとから多糖 複合ファイバーを作製している(66)。コンドロイチン硫酸 $\mathrm{C}$ 溶液をキトサン溶液上に静かに置くことで、界面にそれらの PICからなる膜を形成させる（図6A）。界面からその膜を引 き上げることで紡ぎ、有機溶媒中で乾燥させ最終的に巻き取 る（図6B）。これらの操作によって水溶性の多糖から架橋剂 や糖鎖の化学修飾なしに水に不溶なファイバーが得られる。 コンドロイチン硫酸 $\mathrm{C}$ ／キトサン複合ファイバーは緻密な構 造であり、直径はおよそ $100 \mu \mathrm{m}$ である（図 $6 \mathrm{C}, \mathrm{D} ）$ 。用いる キトサンの分子量と得られるファイバーの関係が調べられて いる。低分子量のキトサンではファイバーは形成されず、高 分子量のものほど高い引張強度を示す傾向が見られている。 


\section{H. Concluding Remarks}

Chitosan is the most widely used polysaccharide for the preparation of structural materials for biomedical use. Chitosan is soluble in aqueous weak acids but not in physiological solutions. It exhibits antimicrobial activity due to its cationic nature and can be degraded enzymatically. In addition, chitin, the parent material of chitosan, is the second most abundant biomass in nature. These properties of chitosan promote its biomaterial applications. One problem associated with the use of chitosan is its higher production cost over those of commonly used synthetic polymers. Support from other chemical fields such as chemical engineering is needed to resolve this problem.

The utilization of functional polysaccharides as structural materials is another important issue. Examples such as the preparation of films having superior mechanical properties from cellulose nanofibers and the use of glycosaminoglycans having specific bioactivities as a component of structural materials are interesting. In addition, the use of polysaccharide PICs is a promising approach for the preparation of structural materials because it makes water-soluble polysaccharides water-insoluble without using the cross-linking or chemical modification of polysaccharide chains. The formation of PICs can be applied to various kinds of ionic polysaccharides, which will expand research on the preparation of functional structural materials from water-soluble bioactive polysaccharides. We are also conducting studies based on our original approaches.

\section{H. 結 語}

キトサンは生物医療利用のための構造材料の作製におい て最も利用されている多糖である。キトサンは弱酸水溶液に 可溶だが生理条件の溶液には不溶である。それはカチオン性 の性質に基づいた抗菌性を示し、酵素的に分解されうる。加 えて母材のキチンは自然界で2番目に多い生物資源である。 そのような特性がキトサンのバイオマテリアル応用を促進し ている。キトサンの利用における一つの問題は、汎用合成高 分子と比較したときのその生産コストの高さである。その問 題を解決するためには化学工学など他の化学の分野からの支 援が必要である。

機能性多糖の構造材料としての利用はもう一つの重要な 問題である。セルロースナノファイバーを利用した力学的特 性に優れたフイルムの作製や、生理活性をもつグリコサミノ グリカン類の構造材料としての利用などの例は興味深い。加 えて多糖PICの利用は架橋や糖鎖の化学修飾なしに水溶性多 糖を水不溶化することができるため、構造材料の作製に用い る手段として将来有望である。PIC形成はさまざまな種類の イオン性多糖に適用可能であり、そのことは水溶性の生物活 性をもった多糖からの機能性構造材料の作製に関する研究分 野をひろげていくことだろう。われわれも独自のアプローチ で検討を進めている。

\section{References}

1. Voet, D., Voet, J. G., and Pratt, C. W. (2012) Fundamental of Biochemistry: Life at the Molecular Level, Forth Edition, Willey.

2. Klemm, D., Heublein, B., Fink, H.-P., and Bohn, A. (2005) Angew. Chem. Int. Ed. 44, 3358-3393.

3. Rinaudo, M. (2008) Polym. Int. 57, 397-430.

4. Sturcova, A., His, I., Apperley, D. C., Sugiyama, J., and Jarvis, M. C. (2004) Biomacromolecules 5, $1333-1339$.

5. Habibi, Y., Lucia, L. A., and Rojas, O. J. (2010) Chem. Rev. 110, 3479-3500.

6. Minke, R., and Blackwell, J. (1978) J. Mol. Biol. 120, 167-181.

7. Sikorski, P., Hori, R., and Wada, M. (2009) Biomacromolecules 10, 1100-1105.

8. Hirsh, J., Anand, S. S., Halperin, J. L., and Fuster, V.; American Heart Association. (2001) Circulation 103, $2994-3018$.

9. Grant, G. T., Morris, E. R., Rees, D. A., Smith, P. J. C., and Thom, D. (1973) FEBS Lett. 32, $195-198$.

10. Rees, D. A. (1981) Pure Appl. Chem. 53, 1-14.

11. Sato, T., Ishii, T., and Okahata, Y. (2001) Biomaterials 22, 2075-2080.

12. Kumar, M. N. V. R., Muzzarelli, R. A. A., Muzzarelli, C., Sashiwa, H., and Domb, A. J. (2004) Chem. Rev. 104, 6017-6084.

13. Agnihotri, S. A., Mallikarjuna, N. N., and Aminabhavi, T. M. (2004) J. Control. Release 100, 5-28.

14. Wong, T. W. (2009) Recent Pat. Drug Deliv. Formul. 3, 5-25.

15. Sasaki, Y., and Akiyoshi, K. (2012) Chem. Lett. 41, 202-208.

16. Morimoto, N., Hirano, S., Takahashi, H., Loethen, S., Thompson, D. H., and Akiyoshi, K. (2013) Biomacromolecules 14, 56-63.

17. Nochi, T., Yuki, Y., Takahashi, H., Sawada, S., Mejima, M., Kohda, T., Harada, N., Kong, I. G., Sato, A., Kataoka, N., Tokuhara, D., Kurokawa, S., Takahashi, Y., Tsukada, H., Kozaki, S., Akiyoshi, K., and Kiyono, H. (2010) Nat. Mater. 9, 572-578.

18. Sawada, S., Sasaki, Y., Nomura, Y., and Akiyoshi, K. (2011) Colloid Polym. Sci. 289, 685-691.

19. Serizawa, T., Sawada, T., Okura, H., and Wada, M. (2013) Biomacromolecules 14, 613-617.

20. Martino, A. D., Sittinger, M., and Risbud, M. V. (2005) Biomaterials 26, 5983-5990.

21. Chow, K. S., and Khor, E. (2000) Biomacromolecules 1, 61-67.

22. Madihally, S. V., and Matthew, H. W. (1999) Biomaterials 20, 1133-1142.

23. Liang, W. H., Kienitz, B. L., Penick, K. J., Welter, J. F., Zawodzinski, T. A., and Baskaran, H. (2010) J. Biomed. Mater. Res. A 94, 1050-1060.

24. Seo, S. J., Kim, I. Y., Choi, Y. J., Akaike, T., and Cho, C. S. (2006) Biomaterials 27, 1487-1495. 
25. Kong, L., Gao, Y., Cao, W., Gong, Y., Zhao, N., and Zhang, X. (2005) J. Biomed. Mater. Res. A 75, $275-282$.

26. Karakeçili, A., and Arıkan, A. (2012) Polym. Compos. 33, 1215-1223.

27. Li, Y., Liu, T., Zheng, J., and Xu, X. (2013) J. Appl. Polym. Sci. 130, 1539-1547.

28. Ma, L., Gao, C., Mao, Z., Zhou, J., Shen, J., Hu, X., and Han, C. (2003) Biomaterials 24, 4833-4841.

29. Tan, H., Gong, Y., Lao, L., Mao, Z., and Gao, C. (2007) J. Mater. Sci. Mater. Med. 18, 1961-1968.

30. Zhong, C., and Chu, C. C. (2012) J. Mater. Chem. 22, 6080-6087.

31. Qi, X. N., Mou, Z. L., Zhang, J., and Zhang, Z. Q. (2014) J. Biomed. Mater. Res. A 102, 366-372.

32. Yusof, N. L., Lim, L. Y., and Khor, E. (2004) Carbohydr. Res. 339, 2701-2711.

33. Kittle, J. D., Wang, C., Qian, C., Zhang, Y. F., Zhang, M. Q., Roman, M., Morris, J. R., Moore, R. B., and Esker, A. R. (2012) Biomacromolecules 13, 714-718.

34. Uragami, T., Matsuda, T., Okuno, H., and Miyata, T. (1994) J. Membr. Sci. 88, 243-251.

35. Silva, R. M., Silva, G. A., Coutinho, O. P., Mano, J. F., and Reis, R. L. (2004) J. Mater. Sci. Mater. Med. 15, 1105-1112.

36. Fukuzumi, H., Saito, T., Iwata, T., Kumamoto, Y., and Isogai, A. (2009) Biomacromolecules 10, 162-165.

37. Tang, C., and Liu, H. (2008) Compos., Part A Appl. Sci. Manuf. 39, 1638-1643.

38. Iwatake, A., Nogi, M., and Yano, H. (2008) Compos. Sci. Technol. 68, 2103-2106.

39. Decher, G. (1997) Science 277, 1232-1237.

40. Gribova, V., Auzely-Velty, R., and Picart, C. (2012) Chem. Mater. 24, 854-869.

41. Ariga, K., Ji, Q. M., Hill, J. P., Bando, Y., and Aono, M. (2012) NPG Asia Mater. 4, el7.

42. Lvov, Y., Onda, M., Ariga, K., and Kunitake, T. (1998) J. Biomater. Sci. Polym. Ed. 9, 345-355.

43. Serizawa, T., Yamaguchi, M., Matsuyama, T., and Akashi, M. (2000) Biomacromolecules 1, 306-309.

44. Thierry, B., Winnik, F. M., Merhi, Y., Silver, J., and Tabrizian, M. (2003) Biomacromolecules 4, 1564-1571.

45. Fu, J., Ji, J., Yuan, W., and Shen, J. (2005) Biomaterials 26, 6684-6692.

46. Caridade, S. G., Monge, C., Gilde, F., Boudou, T., Mano, J. F., and Picart, C. (2013) Biomacromolecules 14, $1653-1660$.

47. Mamedov, A. A., and Kotov, N. A. (2000) Langmuir 16, 5530-5533.

48. Hashizume, M., and Kunitake, T. (2003) Langmuir 19, 10172-10178.

49. Watanabe, H., Vendamme, R., and Kunitake, T. (2007) Bull. Chem. Soc. Jpn. 80, 433-440.

50. Fujie, T., Okamura, Y., and Takeoka, S. (2007) Adv. Mater. 19, 3549-3553.

51. Hagisawa, K., Saito, A., Kinoshita, M., Fujie, T., Otani, N., Shono, S., Park, Y. K., and Takeoka, S. (2013) J. Vasc. Surg. Venous. Lymphat. Disord. 1, 289-297.

52. Hashizume, M., Kobayashi, H., and Ohashi, M. (2011) Colloids Surf. B Biointerfaces 88, 534-538.

53. Picart, C., Lavalle, P., Hubert, P., Cuisinier, F. J. G., Decher, G., Schaaf, P., and Voegel, J. C. (2001) Langmuir 17, 7414-7424.

54. Park, S. Y., Lee, B. I., Jung, S. T., and Park, H. J. (2001) Mater. Res. Bull. 36, 511-519.

55. Karbowiak, T., Debeaufort, F., Champion, D., and Voilley, A. (2006) J. Colloid Interface Sci. 294, 400-410.

56. Tokura, S., Nishi, N., and Noguchi, J. (1979) Polym. J. 11, 781-796.

57. Mikhailov, G. M., Lebedeva, M. F., Nud'ga, L. A., and Petrova, V. A. (2001) Russ. J. Appl. Chem. 74, 1573-1576.

58. Knaul, J. Z., Hudson, S. M., and Creber, K. A. M. J. (1999) Appl. Polym. Sci. 72, 1721-1732.

59. Tamura, H., Tsuruta, Y., Itoyama, K., Worakitkanchanakul, W., Rujiravanit, R., and Tokura, S. (2004) Carbohydr. Polym. 56, $205-211$.

60. Li, L., Yuan, B., Liu, S., Yu, S., Xie, C., Liu, F., Guo, X., Pei, L., and Zhang, B. (2012) J. Mater. Chem. 22, 8585-8593.

61. Desai, K., Kit, K., Li, J., and Zivanovic, S. (2008) Biomacromolecules 9, 1000-1006.

62. Amaike, M., Senoo, Y., and Yamamoto, H. (1998) Macromol. Rapid Commun. 19, 287-289.

63. Yamamoto, H., and Senoo, Y. (2000) Macromol. Chem. Phys. 201, 84-92.

64. Yamamoto, H., Ohkawa, K., Nakamura, E., Miyamoto, K., and Komai, T. (2003) Bull. Chem. Soc. Jpn. 76, $2053-2057$.

65. Ohkawa, K., Takahashi, Y., Yamada, M., and Yamamoto, H. (2001) Macromol. Mater. Eng. 286, 168-175.

66. Iijima, K., Yuyama, K., Asaine, K., Irie, K., and Hashizume, M. (2014) Kobunshi Ronbunshu 71, 11-16.

67. Kokubo, T., Hanakawa, M., Kawashita, M., Minoda, M., Beppu, T., Miyamoto, T., and Nakamura, T. (2004) J. Ceram. Soc. Jpn. 112, $363-367$.

68. Shin, S. J., Park, J. Y., Lee, J. Y., Park, H., Park, Y. D., Lee, K. B., Whang, C. M., and Lee, S. H. (2007) Langmuir 23, $9104-9108$.

69. Onoe, H., Okitsu, T., Itou, A., Kato-Negishi, M., Gojo, R., Kiriya, D., Sato, K., Miura, S., Iwanaga, S., Kuribayashi-Shigetomi, K., Matsunaga, Y. T., Shimoyama, Y., and Takeuchi, S. (2013) Nat. Mater. 12, 584-590. 
Profile of the Authors

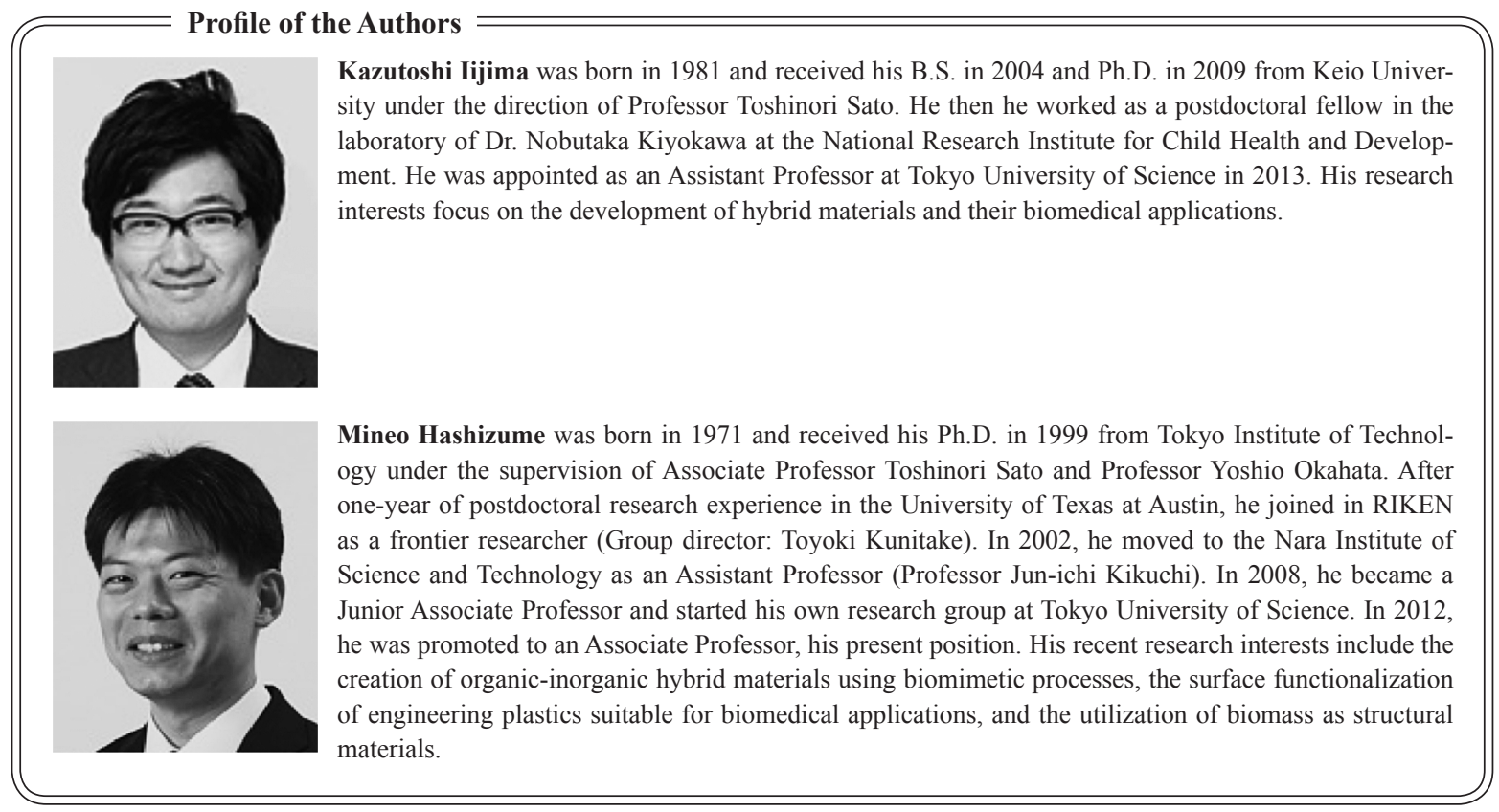

